\title{
Effect of Drying Temperature on Physiochemical Properties of Powder from Blanched and Unblanched Lemon Peel and Sensory Quality Evaluation of the Powder Fortified Biscuits
}

\author{
Joysree Roy, Santo Roy, Md. Julfikar Ali, Md. Rubel Hossain, Md. Sazzat Hossain Sarker* \\ Department of Food Engineering and Technology, Hajee Mohammad Danesh Science and Technology \\ University, Dinajpur, Bangladesh \\ E-mail: mshsarker_hstu@yahoo.com,joysree.tithi.18@gmail.com
}

Received: 10 February 2021; Accepted: 5 March 2021; Available online: 10 April 2021

\begin{abstract}
Preparation of biscuit incorporating lemon peel powder can be a new approach in formulating fortified fast food. This investigation was made to evaluate quality of prepared biscuits with lemon peel powder. The effect of temperature on drying time and physiochemical properties of lemon peel powder and their effects on biscuits were also examined. Two drying temperatures $\left(65^{\circ} \mathrm{C}\right.$ and $\left.75^{\circ} \mathrm{C}\right)$ were employed for both blanched and unblanched lemon peel. The formulated biscuit samples incorporating $1 \%$ lemon peel powder were compared with control biscuits which were prepared with $100 \%$ wheat flour. It took longer time (18 hr) for drying of blanched sample at $65{ }^{0} \mathrm{C}$ whereas shorter time $(8 \mathrm{hr})$ was required for that of blanched sample at $75^{\circ} \mathrm{C}$. There was a significant decrease in the physiochemical properties of lemon peel powder with the increase of temperature except protein and fibre content. In addition, moisture content of the unblanched sample was found to be lower than the blanched sample at the same temperature. Significantly higher ascorbic acid was obtained by the unblanched samples. Protein and fibre content for both unblanched and blanched sample at the same temperature were found to be higher. All the samples were significantly different at $5 \%$ level of significance for overall acceptability. Biscuits prepared with unblanched dried lemon peel powder (at $65^{\circ} \mathrm{C}$ ) sample secured the highest score in case of all the sensory parameters. Therefore, quality fortified biscuit can be prepared commercially by incorporating $1 \%$ lemon peel powder in wheat flour for the fast food consumer.
\end{abstract}

Keywords: Lemon peel powder; Fortified biscuit; Sensory evaluation; Blanching; Drying temperature

\section{Introduction}

In many developing as well as developed countries, the utilization of food processing left-over's is often confined by lack of knowledge about their nutritional and commercial value and as a consequence, most of them are disposed of without being reused. Thus, the proper management of the residues constitutes an everlasting problem for the citrus industries. Lemon is one of the predominant citrus crops. Approximately 13.7 million tons of lemon and lime was produced annually whereas total production of citrus fruits is over 110 million tons in the earth [1]. In the fiscal year 2017-2018, 23 thousand metric tons of citrus fruits were grown in Bangladesh [2]. It was reported that citrus peels hold $50 \%$ to $65 \%$ of the total mass of the fruits and remain the major residue after processing resulting in huge amounts of peel which are a good source of contamination [3].

Lemon (Citrus limon L. Burm) is the fruit of a citrus plant which is familiarized by its light yellow colour and pleasant flavor and contained high acid and dietary fibre content [4]. By-products obtained from lemon are peel, pulp, seed and wastewater and these are known to be rich in bioactive compounds such as flavonoids, limonoids, phenolic acids, coumarins, furocoumarins, polymethoxyflavones, and carotenoids [5]. Citrus fruits are mainly used for juice, oil and pectin production and are underutilized sources for dietary fibre and antioxidants. These definite properties of dietary fibre take part in a vital role in the prevention and treatment of obesity, atherosclerosis, coronary heart diseases, cancer and diabetes [6]. By-products can be used to add nutritional and financial value to productive chains after processing into flours [7, 8].

Kaysar et al., [9] reported that lemon contains great number of citric acid (4.52 \% to $5.82 \%$ ). Janati et al., [10] observed mineral compositions of lemon peel were sodium (Na) (755.50 \pm 0.058$) \%$, potassium $(\mathrm{K})$

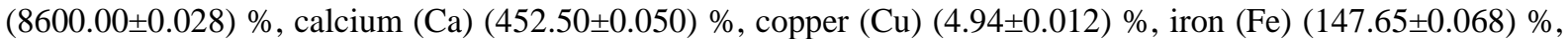
magnesium (Mg) (1429.50 \pm 0.008$) \%$, zinc (Zn) (13.94 \pm 0.007$) \%$, phosphorus (P) $(6656.25 \pm 0.17) \%$ and physicochemical parameters of lemon peel were protein $9.42 \%$, fiber $15.18 \%$, ash $6.26 \%$, fat $4.98 \%$. 
The food industries have shown keen interests in making the best usage of citrus by products. Thousands of tons of by-products are produced throughout citrus juice extraction procedure [11]. Russo et al., [5] revealed that lemon by-products (seeds, peels and pulps, waste waters) can be analyzed and reused to get nutraceuticals and dietary fibre for individual dietary purposes those produced after industrial processing of lemon fruits. Blanching is a pretreatment before vegetables go through several processes [12]. Both blanching and drying enhanced dietary fibre components, colour values and hydration characteristics [13]. To inactivate enzymatic reactions during processing, blanching is generally carried out before drying [14]. Marey and Shoughy [15] reported that quick drying is very essential to reduce the moisture content to a safe level previous to further processing because of the high moisture content of the citrus residuals after processing.

Biscuit is a very popular processed product and is no more limited in uses to higher income society. Despite the arrival of modern, largely accomplished and automatic biscuit making plant enormous number of people, mainly in semi-urban and rural areas, still have a preference on fresh biscuits from local bakeries because of their wide and low price varieties. Considering the above discussion, the objective of this research was to investigate the effect of drying temperatures on the physicochemical properties of powder from blanched and unblanched lemon peel and to evaluate the sensory quality of the lemon peel powder fortified biscuits.

\section{Materials and methods}

Fresh lemons of 'Dorshapo' variety were collected from a local market. These lemons were washed with clean water to remove dirt, sand and other undesirable materials before use. Peel was removed by knives. Cleaned and washed lemon peels were dried to produce lemon peel powder which was used for biscuit preparation. Wheat flour, egg, sugar, baking powder, margarine, salt, oil and other ingredients were procured from the local market. Other ingredients were collected from laboratory stocks. High density polyethylene (HDPE) sacks were used for packaging and storing of the prepared powder samples for further use.

\subsection{Preparation of lemon peel powder}

Lemon peel powder (Figure 1) was prepared by following procedure presented in the flow chart as shown in Figure 2. Some amount of peels was blanched in water at $70^{\circ} \mathrm{C}$ for $3 \mathrm{~min}$ and the remaining amount was kept unblanched. Both unblanched and blanched samples were dried in hot air oven (Binder, Model FD 23, Chaina) using $65^{\circ} \mathrm{C}$ (18 hours for blanched and 12 hours for unblanched sample) and $75^{\circ} \mathrm{C}$ (14 hours for blanched and 12 hours for unblanched sample) temperature following the procedure of Akter et al., [13] and availing our laboratory facilities. Lemon peels were dried spreading in trays as single layer. The dried lemon peels were blended to make powder using a Blender (Jaipan, CM/L-7360065, Japan). The ground samples were screen through sieve (MIC \#40) and then the powder was packed in HDPE sacks and stored at room temperature for further use in preparation of biscuits.

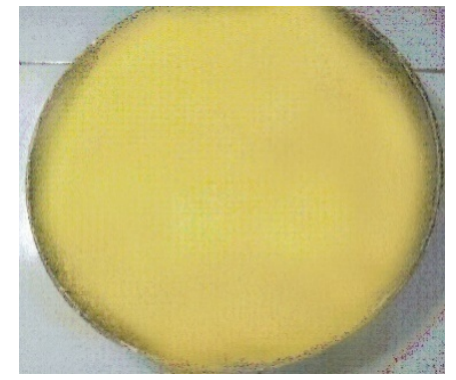

Figure 1. Photographic view of lemon peel powder

\subsection{Preparation of biscuit incorporating lemon peel powder with wheat flour}

Initially, attempts were taken to examine the feasibility of prepared biscuits using various percentages of peel powder with main ingredients of wheat flour. After several trials best formulation was obtained at $1 \%$ level of substitution in wheat flour. For formulation of $100 \mathrm{~g}$ biscuit wheat flour (41.5 g), lemon peel powder (1 g), sugar (10 g), milk powder (6 g), baking powder (0.5 g), dalda (10 g), salt (0.5 g), egg (20 g), oil (10 g) and black cumin $(0.5 \mathrm{~g})$ were taken. The dalda was kneaded until it was turned into paste form. Then sugar powder was mixed with the dalda paste. After complete mixing of dalda and sugar, wheat flour, lemon peel powder, milk powder, salt, baking powder and vanilla essence were mixed thoroughly to make adequate dough and kept for few minutes. Then the dough was rolled to a uniform sheet of thickness. The sheet was then cut according to the desired shape and size of biscuits with a cutter and the biscuits were baked in the baking oven at $180{ }^{\circ} \mathrm{C}$ for 20 minutes. Backed 
biscuits, were cooled to ambient temperature, were shown in Figure 3 and packed in high density polythene bags. The packs were then sealed and stored at room temperature for future quality evaluation.

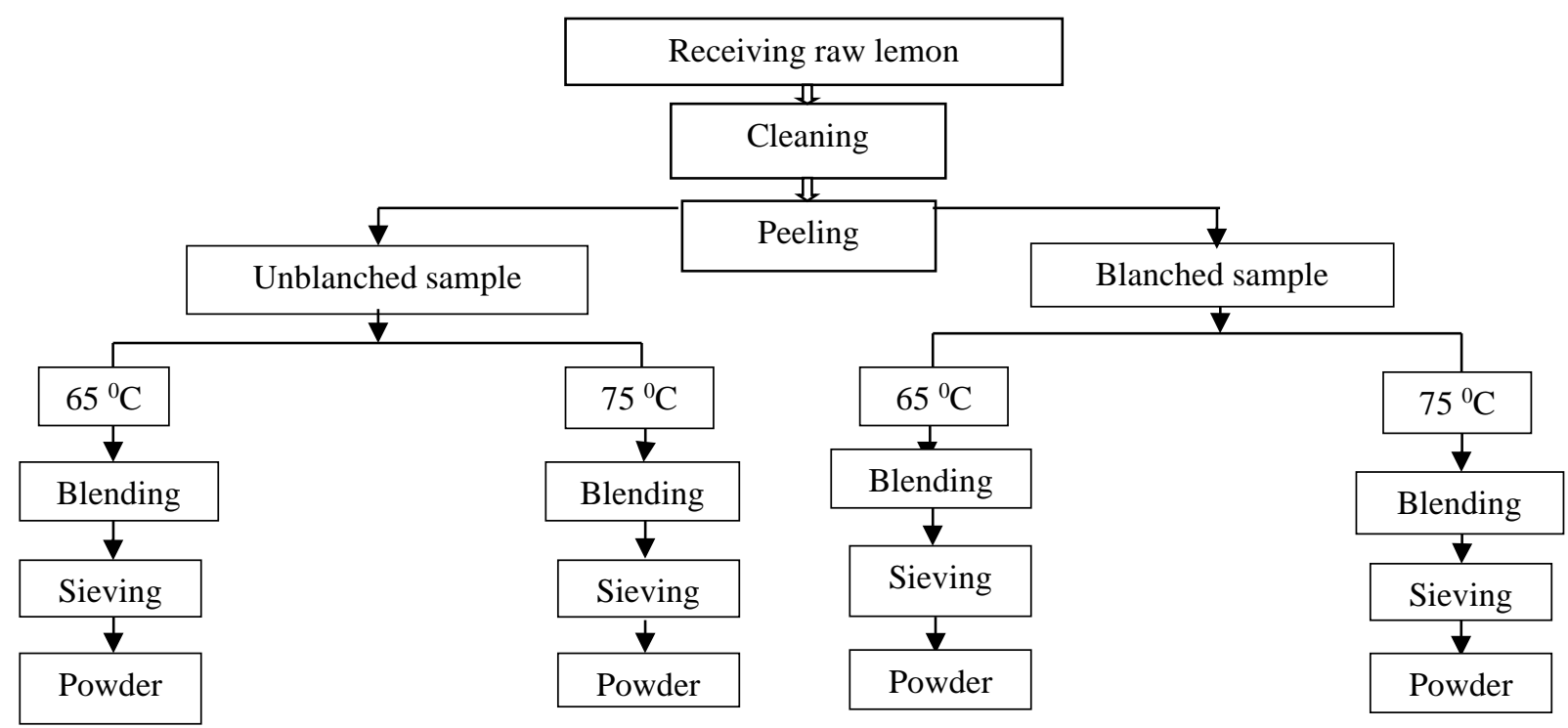

Figure 2. Process flow diagram for lemon peel powder preparation

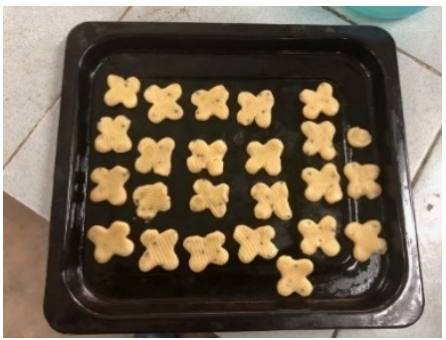

i) Unblanched

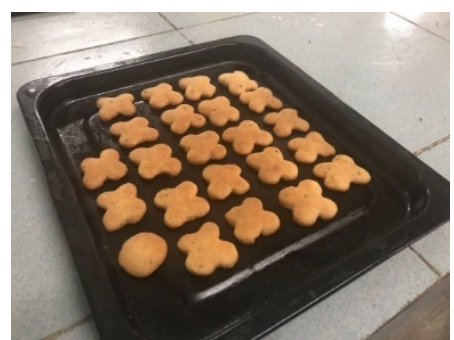

ii) Blanched

a. Biscuits from lemon peel powder dried at $65^{\circ} \mathrm{C}$

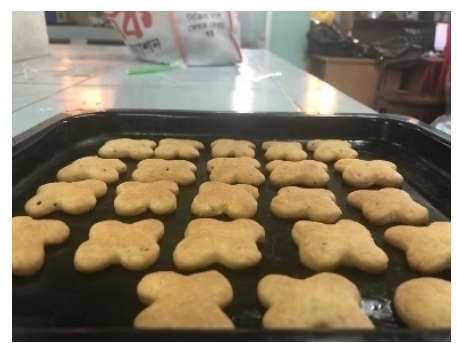

iii) Unblanched

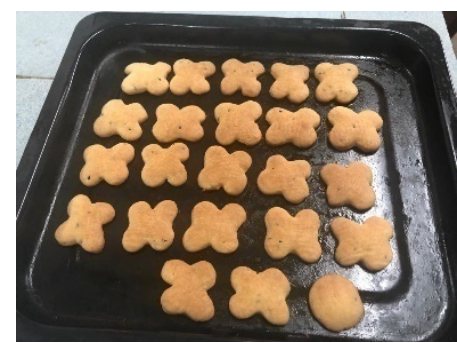

iv) Blanched

b. Biscuits from lemon peel powder dried at $75^{\circ} \mathrm{C}$

Figure 3. Biscuit samples fortified with $1 \%$ dried lemon peel powder

\subsection{Analysis of physico-chemical properties of lemon peel powder}

The prepared lemon peel powder samples were analyzed for moisture, protein, ascorbic acid, fiber content and $\mathrm{pH}$.

\subsubsection{Determination of moisture content}

Moisture content was determined by the Association of Official Analytical Chemists method [16]. $5 \mathrm{~g}$ of sample was taken in the crucible and weighed. The crucible was placed in the oven and was dried at temperature $105^{\circ} \mathrm{C}$ for 24 hours. After drying the crucible was removed from the oven and cooled in desiccators and then weighed. Drying, cooling and weighing were repeated until 2 consecutive weights were the same, for accuracy at least 3 samples were dried in the oven and average moisture content was calculated as follows: 
$\%$ Moisture $=\frac{\text { Initial weight }- \text { final weight }}{\text { Initial weight }} \times 100$

\subsubsection{Determination of protein content}

The crude protein content was determined by following the micro Kjeldahl method [16]. Sample (0.5 g) was mixed with $10 \mathrm{ml}$ of concentrated $\mathrm{H}_{2} \mathrm{SO}_{4}$ in digestion flask. A tablet of selenium catalyst was added to it before it was heated under a fume cup board until a clear solution was obtained (the digest). Then $10 \mathrm{ml}$ of the digest was mixed with equal volume of $45 \% \mathrm{NaOH}$ solution in a Kjeldahl distillation apparatus. The mixture was distilled into $10 \mathrm{ml}$ of $40 \%$ boric acid containing 3 drops of mixed indicator (methyl red). A total of $50 \mathrm{ml}$ of distillates was collected and titrated against 0.02 N EDTA from green to a deep red end point. A reagent blank was also digested, distilled and titrated. The percentage of nitrogen content and hence the protein content was calculated using the formula below:

$$
\% \text { Nitrogen }=\frac{(I B R-F B R) \times N \times 0.014 \times D F}{\text { Weight of dry sample }} \times 100
$$

where, $\mathrm{DF}=$ Dilution factor, $\mathrm{T}=$ Titer value $=(\mathrm{IBR}-\mathrm{FBR}), \mathrm{W}=$ Weight of sample, $0.014=$ Constant value, $\mathrm{N}=$ Normality of titrant value $\left(0.02 \mathrm{~N} \mathrm{H}_{2} \mathrm{SO}_{4}\right)$. Crude protein was obtained by multiplying the corresponding total nitrogen content by a conventional factor of 6.25 . Thus, crude protein $(\%)=\%$ of $\mathrm{N} \times 6.25$.

\subsubsection{Determination of ascorbic acid}

Ascorbic acid (Vitamin-C) was analyzed by using titration method of Rangana [18]. $10 \mathrm{~g}$ sample was mixed with a $100 \mathrm{ml}$ of $3 \% \mathrm{HPO}_{3}$ and filtered through a filter paper. Filtered sample was titrated against the dye solution which was made of $200 \mathrm{ml}$ with $50 \mathrm{mg}$ of the sodium salt of 2,6-dichlorophenol indophenol, $42 \mathrm{mg}$ of sodium bicarbonate and distilled water. Appearance of pink color indicated the end point of titration. In a titration method, dye factor was calculated using same procedure with known ascorbic acid. Ascorbic acid (Vitamin-C) was estimated by the following equation.

$$
\text { Ascorbic acid }\left(\frac{\mathrm{mg}}{100 \mathrm{~g}}\right)=\frac{\text { Titre } * \text { dye fator } * \text { volume made up }}{\text { volume of filtrate taken } * \text { weight of sample }} \times 100
$$

\subsubsection{Determination of fiber content}

The crude fiber content of the samples was determined by sequentially acid and alkali hydrolysis followed by ignition of the residue as described by the method AOAC [17]. About $1 \mathrm{~g}$ of sample (oven dried) was taken in a $1 \mathrm{~L}$ beaker and the beaker was refluxed to boiling point with $200 \mathrm{ml}$ of $1.25 \%$ sulphuric acid. Then it was boiled for 30 minutes and filtered through Whatman no.42. After that the residue was taken in a beaker again and mixed with $200 \mathrm{ml}$ of $1.25 \% \mathrm{NaOH}$ and boiled for 30 minutes. Again, it was filtered and residue was kept in an oven for drying for 2 hours. It was then cooled in a desiccator and weighed. After that, the sample was ignited in a muffle furnace at $600{ }^{\circ} \mathrm{C}$ for $4 \mathrm{hrs}$. The fiber content was determined by following equation.

$$
\% \text { Fiber }=\frac{\text { Initial weight }- \text { final weight }}{\text { Sample weight }} \times 100
$$

\subsubsection{Determination of $\mathrm{pH}$}

$\mathrm{pH}$ of dried lemon peel powder was measured by standard procedure through a digital pH meter (HI 2211, Hanna Instruments, Romania) [18]. Some distilled water was added with the powder to prepare a juice. Firstly, pH meter was calibrated through buffer solution ( $\mathrm{pH}-4$ and $\mathrm{pH}-7)$. Then, the electrode was dipped into the juice and the reading was recorded.

\subsection{Determination of colour}

The colour of the dried lemon peel powder was measured using a colorimeter BIOBASE-Lab colorimeter (Qingdao, China). Changes in colour were measured by colorimetric evaluation using three parameters $\mathrm{L}$ value [lightness, ranging from zero (black) to 100 (white)], a value [ranging from +60 (red) to -60 (green)] and b value [ranging from +60 (yellow) to -60 (blue)]. The magnitude of total colour change was calculated by the following formula $[19,20]$.

$$
\text { Total colour change }(\Delta \mathrm{E})=\left[\left(\mathrm{L}-\mathrm{L}_{0}\right)^{2}+\left(\mathrm{a}-\mathrm{a}_{0}\right)^{2}+\left(\mathrm{b}-\mathrm{b}_{0}\right)^{2}\right]^{1 / 2}
$$

where $\mathrm{L}_{0}=50.61, \mathrm{a}_{0}=-5.60$ and $\mathrm{b}_{0}=31.66$ were the colour values of the fresh sample and $\mathrm{L}$, $\mathrm{a}$ and $\mathrm{b}$ represented the individual values at particular storage time, to evaluate the total colour change of the dehydrated product. Three 
measurements were made at different locations on the surface of the samples, and the procedure was repeated on triplicate samples to get the average values.

\subsection{Sensory evaluation of lemon peel powder fortified biscuits}

Biscuits fortified with lemon peel powders were coded with different numbers and submitted to sensory evaluation by thirty panelists being requested to give number on a 9 point hedonic scale. The panelists were asked to rate each sensory attribute using the control biscuits as the basic for assessment. For statistical analysis of sensory data, biscuits were evaluated for color, flavour, texture, and overall acceptability on a 9-point hedonic scale [21].

\subsection{Statistical analysis}

The statistical software programme SPSS (IBM/version 22) was used for the analysis of variance (ANOVA) on sensory quality attributes of lemon peel powder fortified biscuit. Duncan's Multiple Range Test (DMRT) was also employed for comparisons of the mean values of the scores on physico-chemical properties of lemon peel powder and sensory attributes of the biscuits at $\mathrm{p} \leq 0.05$.

\section{Results and discussion}

\subsection{Effect of drying temperature on physio-chemical properties of unblanched and blanched lemon peel powder}

\subsubsection{Moisture content}

Figure 4 reveals the variation in moisture content of powder samples dried in hot air oven at $65^{\circ} \mathrm{C}$ and $75^{\circ} \mathrm{C}$. Powder obtained from blanched sample contained significantly lower moisture content than the unblanched sample dried at $65^{\circ} \mathrm{C}$ and $75^{\circ} \mathrm{C}$. Unblanched (dried at $65^{\circ} \mathrm{C}$ ) lemon peel powder had the highest moisture content $(9.3 \%)$ and blanched (dried at $65^{\circ} \mathrm{C}$ ) lemon peel powder secured the lowest moisture content $(6.7 \%)$. From Figure 4 , it is noticed that with the increase of drying temperature there was a noticeable decrease in the moisture content. Marey and Shoughy [15] reported similar results for drying of orange and mandarin peel at $60^{\circ} \mathrm{C}$ and $70^{\circ} \mathrm{C}$. Again, it was observed that moisture content of the blanched samples was higher than the unblanched samples due to the blanching effect of the lemon peel. Knowledge of the required final moisture content will prevent over-drying and thus decrease the drying time, mass losses and risk of quality deterioration, drying to lower moisture content will increase the operation costs and mass losses without increasing the storage safety [22].

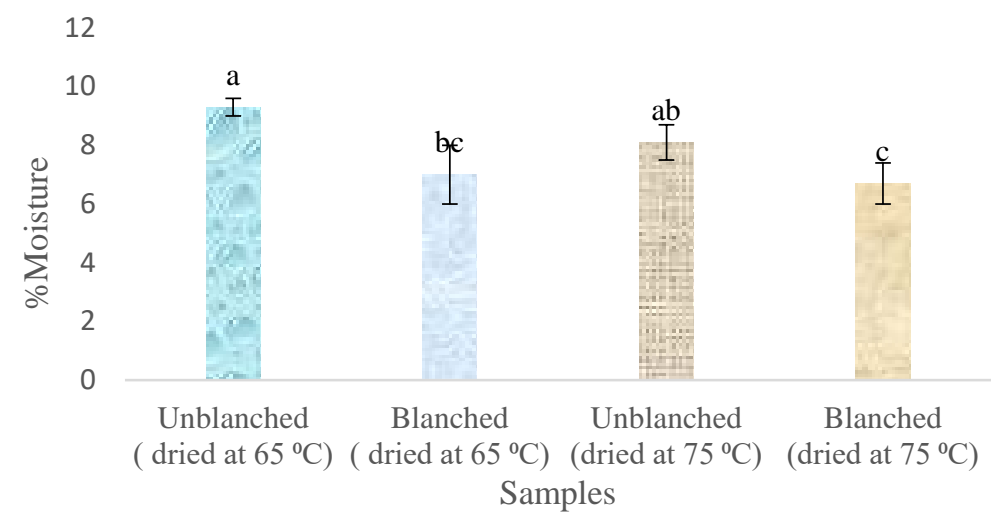

Figure 4. Effect of drying temperature on moisture content of unblanched and blanched lemon peel powder. Results are represented as mean \pm standard deviation.

\subsubsection{Protein content}

The percent varies of protein content were presented in Figure 5. It exhibited the difference in protein content of powder samples dried in hot air oven at $65^{\circ} \mathrm{C}$ and $75^{\circ} \mathrm{C}$. Unblanched (dried at $75^{\circ} \mathrm{C}$ ) sample was found to contain the highest protein content of $8.49 \%$ while blanched (dried at $65^{\circ} \mathrm{C}$ ) sample had the lowest amount of $6.29 \%$. Significant difference was observed in protein content for the two temperatures. But, there was no significant difference for the blanched and unblanched samples at the same temperature. The experimental values were higher than the values of Ashoush and Gadallah [21] who reported the protein content of $50^{\circ} \mathrm{C}$ dried mango peel powder was (3.6 \pm 0.15$)$. It was found that the protein content increased with the applying of temperature. It is interesting that the protein content of the unblanched samples was higher than that of the blanched samples dried at the same 
temperature probably due to the increased protein denaturation and increased diffusion of soluble components into blanching medium [23].

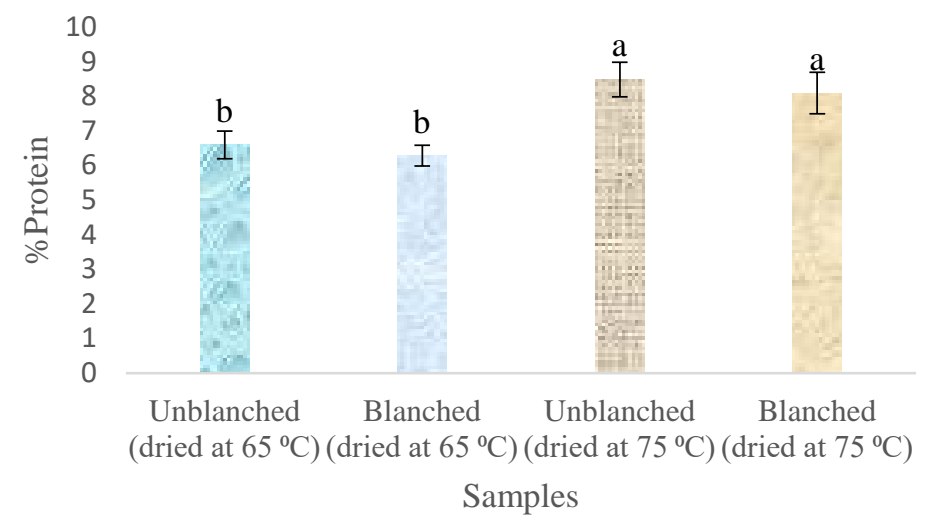

Figure 5. Effect of drying temperature on protein content of unblanched and blanched lemon peel powder. Results are represented as mean \pm standard deviation.

\subsubsection{Ascorbic acid}

Ascorbic acid (Vitamin C) of lemon peel powder samples was in the range of (5.7-13.8) mg/100g (Figure 6). The highest ascorbic acid was obtained in unblanched (dried at $65^{\circ} \mathrm{C}$ ) sample which was $13.8 \mathrm{mg} / 100 \mathrm{~g}$ and the lowest was in blanched (dried at $75^{\circ} \mathrm{C}$ ) sample. Significant difference was observed among the samples for ascorbic acid content. Unblanched samples had significantly higher ascorbic acid content than the blanched samples. The figure showed that increasing drying temperatures from 65 to $75{ }^{\circ} \mathrm{C}$ tends to increase the losses of ascorbic acid content. Similar observations were found by Akhter et al., [13] for persimmon peel powder.

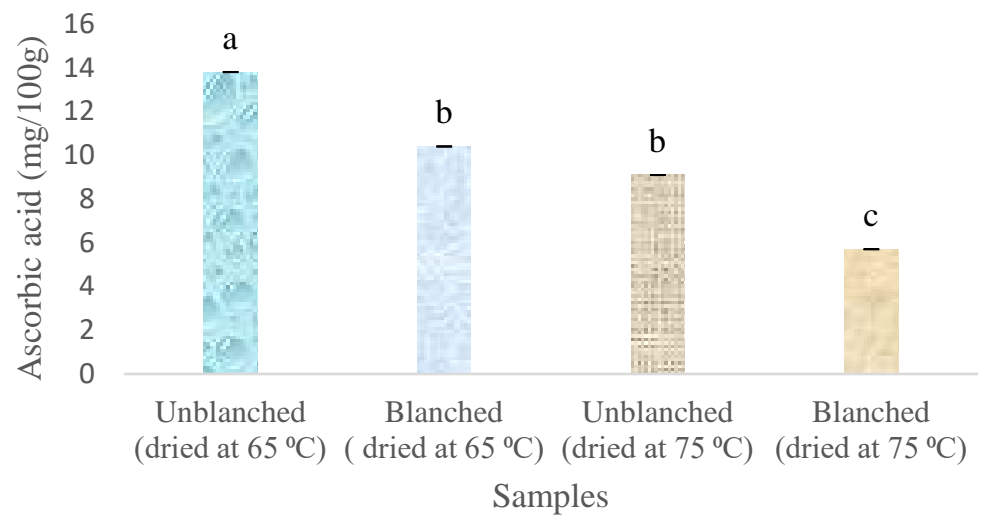

Figure 6. Effect of drying temperature on ascorbic acid content of unblanched and blanched lemon peel powder. Results are represented as mean \pm standard deviation.

\subsubsection{Fibre content}

Figure 7 expresses the variation in fibre content of samples dried in $65^{\circ} \mathrm{C}$ and $75^{\circ} \mathrm{C}$ in hot air oven. Maximum value (17.24\%) of fibre content was obtained by unblanched sample which was dried at $65^{\circ} \mathrm{C}$ and minimum value (15.00\%) was gained by the blanched one at the same temperature. The observed fibre content by Ashoush and Gadallah [21] was $(9.33 \pm 0.61)$ for $50^{\circ} \mathrm{C}$ dried mango peel powder which was lower than the stated value. It was found that the unblanched samples gave higher fibre content than the blanched samples. Dietary fibres have both nutritional and technological properties that can be used in the formulation of foods ensuing in texture modification and enhancement of the stability of the food during production and storage [24]. Many authors added citrus fibres to cooked and dry-cured sausages [25], beef burgers [26], and fermented milk containing probiotics [27]. Enrichment of cereal bakery products with fruit fiber would enhance the nutritional quality of the product better than cereal bran sources [28]. 


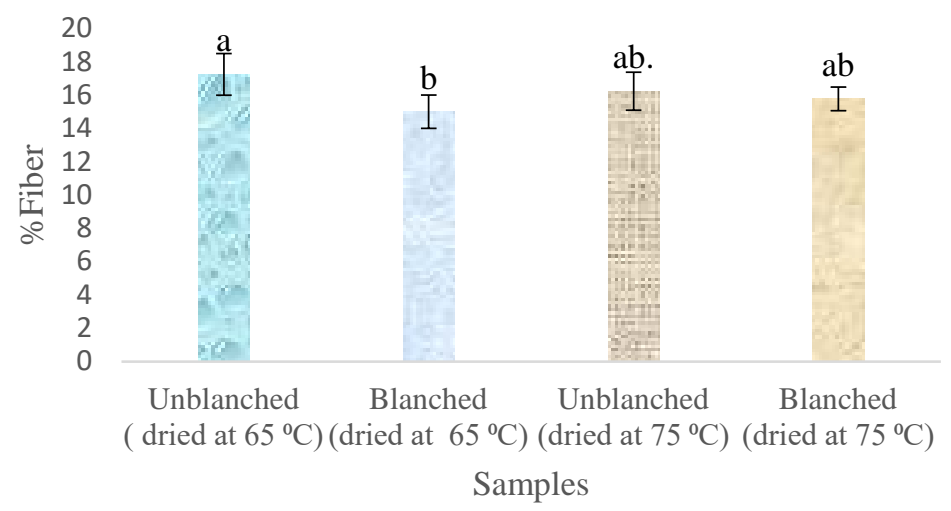

Figure 7. Effect of drying temperature on fiber content of unblanched and blanched lemon peel powder. Results are represented as mean \pm standard deviation.

\subsection{5 $\mathrm{pH}$ value}

The $\mathrm{pH}$ value of dried lemon peel powder was presented in Figure 8. Maximum pH value (5.3) was observed in unblanched (dried at $75{ }^{\circ} \mathrm{C}$ ) lemon peel powder as compared to the other samples. Unblanched samples obtained the higher $\mathrm{pH}$ value than the blanched samples. It may be the effect of pre-treatment. Lemon peel powder dried at $75^{\circ} \mathrm{C}$ got the superior $\mathrm{pH}$ values than the samples dried at $65^{\circ} \mathrm{C}$. The $\mathrm{pH}$ differences found in different treatments may be due to the different moisture contents [29].

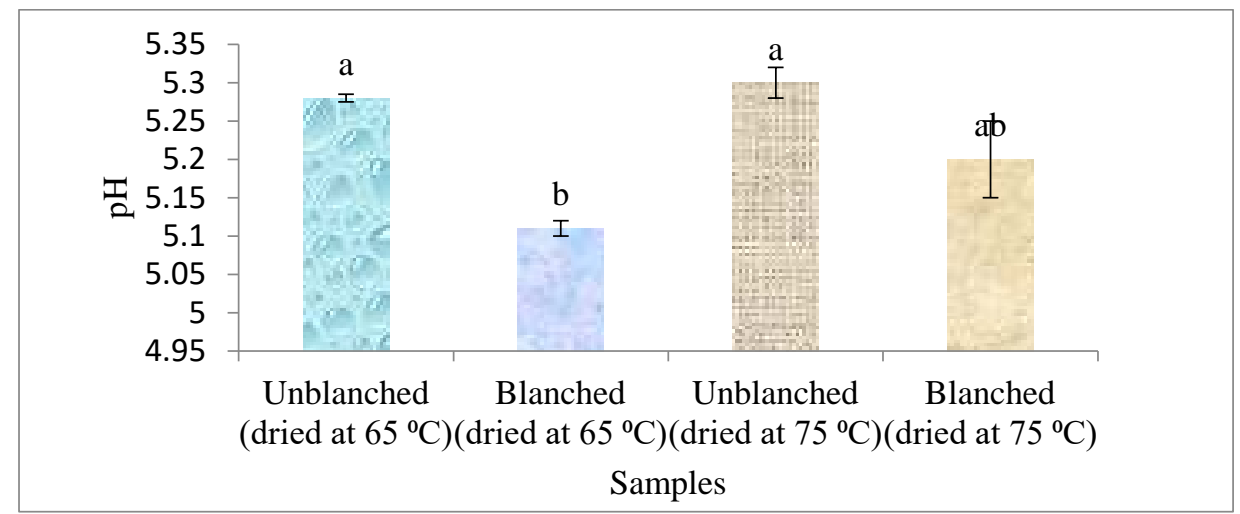

Figure 8. Effect of drying temperature on $\mathrm{pH}$ of unblanched and blanched lemon peel powder. Results are represented as mean \pm standard deviation.

\subsection{Color of lemon peel powder samples}

Color is an important consistency parameter of powders, and color measurements of different lemon peel powders were shown in Table 1. In this study no significant variation was found for lightness (L), redness (a) and yellowness (b) of the dried lemon peel powder.

Table 1. $\mathrm{L}$, a, b and $\Delta \mathrm{E}$ value of unblanched and blanched lemon peel powder dried at $65^{\circ} \mathrm{C}$ and $75^{\circ} \mathrm{C}$

\begin{tabular}{lcccc}
\hline \multicolumn{1}{c}{ Samples } & L value & a value & b value & $\Delta \mathrm{E}$ \\
\hline Unblanched (dried at $\left.65^{0} \mathrm{C}\right)$ & $68.95 \pm 3.80^{\mathrm{a}}$ & $-0.87 \pm 0.91^{\mathrm{a}}$ & $29.31 \pm 1.43^{\mathrm{a}}$ & $21.96 \pm 1.10^{\mathrm{ab}}$ \\
Blanched (dried at $65^{\circ} \mathrm{C}$ ) & $67.32 \pm 1.08^{\mathrm{a}}$ & $-2.39 \pm 0.48^{\mathrm{a}}$ & $28.72 \pm 2.10^{\mathrm{a}}$ & $13.72 \pm 1.32^{\mathrm{c}}$ \\
Unblanched (dried at $75^{0} \mathrm{C}$ ) & $73.99 \pm 2.52^{\mathrm{a}}$ & $-3.07 \pm 0.15^{\mathrm{a}}$ & $29.33 \pm 1.06^{\mathrm{a}}$ & $23.76 \pm 2.13^{\mathrm{a}}$ \\
Blanched (dried at $\left.75^{\circ} \mathrm{C}\right)$ & $68.75 \pm 1.85^{\mathrm{a}}$ & $-1.22 \pm 0.12^{\mathrm{a}}$ & $28.45 \pm 1.01^{\mathrm{a}}$ & $19.22 \pm 1.46^{\mathrm{b}}$ \\
\hline
\end{tabular}

* [Different letters indicate significant differences $(\mathrm{p} \leq 0.05)$ among the samples]

* Mean values \pm standard deviation (SD)

From Table 1, the higher $\mathrm{L}$ value was found in unblanched sample dried at $75^{\circ} \mathrm{C}(73.99)$ and the lower was observed in blanched sample dried at $65^{\circ} \mathrm{C}$ (67.32). Unblanched samples got comparatively higher scores than blanched samples for $\mathrm{L}$ value. In case of a value, that represent redness was observed higher for unblanched sample dried at $75^{\circ} \mathrm{C}$ and lower in unblanched sample dried at $65^{\circ} \mathrm{C}$. The $\mathrm{b}$ values which represent yellowness, the highest yellowness (29.33) was observed in unblanched sample dried at $75^{\circ} \mathrm{C}$ followed by unblanched sample dried at $65^{\circ} \mathrm{C}$ (29.31). It was figure out that unblanched samples got higher b value than the blanched samples. The lowest 
b value was observed in blanched sample dried at $75^{\circ} \mathrm{C}$ (28.45). Minimum colour difference (13.72) was observed in blanched sample dried at $65^{\circ} \mathrm{C}$ which was significantly different from the others. Unblanched sample dried at $75^{\circ} \mathrm{C}$ had the maximum color difference $(\Delta \mathrm{E})$ value (23.76) as compared to the other samples.

\subsection{Sensory evaluation of biscuit sample}

Sensory evaluation results as shown in Table 2 revealed that there were significant differences $(p<0.05)$ observed for colour, flavour, texture, taste and overall acceptability for the fortified lemon peel powder biscuits which was previously dried at $65^{\circ} \mathrm{C}$ and $75^{\circ} \mathrm{C}$ in hot air oven. Biscuit from unblanched peel dried at $65^{\circ} \mathrm{C}$ obtained the highest score $(8.25 \pm 0.45)$ and control sample secured $(8.08 \pm 1.07)$ the second position for colour. These two samples were significantly different from the others. In case of flavour, biscuit from unblanched peel dried at 65 ${ }^{0} \mathrm{C}(8.25 \pm 0.45)$ got the highest score and differed significantly from other samples. It was observed that unblanched samples got higher score than that of blanched samples for both colour and flavour. In addition, colour score decreased with the rise of temperature. Therefore, due to the enzymatic browning, brightness and yellowness of the biscuits may be decreased as reported by Ajila et al., [28].

Table 2. Mean scores on sensory attributes of biscuits fortified with lemon peel powder

\begin{tabular}{lccccc}
\hline \multicolumn{1}{c}{ Biscuit Sample } & Color & Flavor & Texture & Taste & $\begin{array}{c}\text { Overall } \\
\text { Acceptability }\end{array}$ \\
\hline Unblanched (dried at $\left.65^{0} \mathrm{C}\right)$ & $8.25 \pm 0.45^{\mathrm{a}}$ & $8.25 \pm 0.45^{\mathrm{a}}$ & $7.75 \pm 0.45^{\mathrm{a}}$ & $8.00 \pm 0.00^{\mathrm{a}}$ & $8.06 \pm 0.22^{\mathrm{a}}$ \\
Blanched (dried at $65^{0} \mathrm{C}$ ) & $6.75 \pm 0.45^{\mathrm{b}}$ & $6.25 \pm 0.45^{\mathrm{c}}$ & $6.58 \pm 0.51^{\mathrm{b}}$ & $6.50 \pm 0.52^{\mathrm{c}}$ & $6.52 \pm 0.20^{\mathrm{d}}$ \\
Unblanched (dried at $75^{0} \mathrm{C}$ ) & $7.25 \pm 1.14^{\mathrm{b}}$ & $7.25 \pm 0.45^{\mathrm{b}}$ & $6.25 \pm 0.86^{\mathrm{b}}$ & $6.75 \pm 0.45^{\mathrm{c}}$ & $7.00 \pm 0.30^{\mathrm{c}}$ \\
Blanched (dried at $75^{0} \mathrm{C}$ ) & $5.92 \pm 0.29^{\mathrm{c}}$ & $6.33 \pm 0.49^{\mathrm{c}}$ & $5.58 \pm 0.51^{\mathrm{c}}$ & $5.92 \pm 0.29^{\mathrm{d}}$ & $5.94 \pm 0.19^{\mathrm{e}}$ \\
Control Sample & $8.08 \pm 1.07^{\mathrm{a}}$ & $7.25 \pm 0.87^{\mathrm{b}}$ & $7.58 \pm 0.51^{\mathrm{a}}$ & $7.58 \pm 0.51^{\mathrm{b}}$ & $7.63 \pm 0.29^{\mathrm{b}}$ \\
\hline
\end{tabular}

* Mean values \pm standard deviation (SD)

* Means followed by different superscript letters within a column are significantly different at $5 \%$ level of significance

In terms of texture, unblanched peel dried at $65^{\circ} \mathrm{C}$ obtained the highest score $(7.75 \pm 0.45)$ and equally acceptable with the control biscuit while blanched sample dried at $75^{\circ} \mathrm{C}$ obtained the lowest score (5.58 \pm 0.51$)$. It is obvious that the score obtained by the samples dried at $65^{\circ} \mathrm{C}$ (unblanched and blanched) is higher than that of the samples dried at $75{ }^{\circ} \mathrm{C}$ for texture. Again, for taste results revealed that sample unblanched peel dried at $65^{\circ} \mathrm{C}$ secured the maximum score $(8.00 \pm 0.00)$ and blanched sample dried at $75{ }^{\circ} \mathrm{C}$ secured the minimum score (5.92 \pm 0.29$)$. From Table 2, it was clear that unblanched samples got the highest score than the blanched samples for taste. According to taste analysis, acceptability decreased with the rise of temperature. For overall acceptability, all the samples were significantly different at $5 \%$ level of significance. Unblanched peel dried at $65{ }^{\circ} \mathrm{C}$ obtained the uppermost score (8.06 \pm 0.22$)$, control sample got the second highest score $(7.63 \pm 0.29)$ and blanched sample dried at $75{ }^{\circ} \mathrm{C}$ obtained the lowest score $(5.94 \pm 0.19)$ for overall acceptability. The score for overall acceptability obtained by the unblanched samples were greater than those of the blanched samples. Considering the colour, flavour, texture, taste and overall acceptability, unblanched peel dried at $65^{\circ} \mathrm{C}$ is significantly different from other samples and got the highest score for all the cases. Therefore, biscuits with overall acceptable quality can be prepared using $1 \%$ lemon peel powder formulations.

\section{Conclusion}

The feasibility of incorporating lemon peel powder in preparation of biscuit was examined. For preparing lemon peel powder, it was observed that with the increase of drying temperature there was a significant decrease in the moisture content, time and ascorbic acid content of lemon peel powder. But, protein content and $\mathrm{pH}$ value increased with the increase of temperature. A notable effect was found for nutritional composition of lemon peel powder after blanching. The investigation had demonstrated that incorporation of $1 \%$ lemon peel powder (unblanched and dried at $65^{\circ} \mathrm{C}$, blanched and dried at $65^{\circ} \mathrm{C}$, unblanched and dried at $75^{\circ} \mathrm{C}$, blanched and dried at $75^{\circ} \mathrm{C}$ ) in the biscuits affected the quality attributes. For overall acceptability, all the biscuit samples were found significantly different at $5 \%$ level of significance. To conclude, unblanched peel dried at $65^{\circ} \mathrm{C}$ is more acceptable than the others not only for sensory evaluation result but also for highest fibre content of that sample. In addition, the findings of the present study may help in developing profitable processing techniques in manufacturing of fortified biscuits by effective utilization of food industry by-product lemon peel powder. Further research can be done to develop other bakery and confectionary products using lemon peel.

\section{References}


[1] Yara. Crop nutrition: world citrus production. http://www.yara.us/agriculture/crops/citrus/keyfacts/worldcitrus-production. (accessed on April 9, 2017).

[2] BBS. Statistical yearbook of Bangladesh. Bangladesh Bureau of statistics, Ministry of planning, Dhaka, Bangladesh. 39 th Edition. 2019.

[3] Mandalari G, Bennett RN, Bisignano G, Saija A, Dugo G, Lo C. Characterization of flavonoids and pectins from bergamot (Citrus bergamia Risso) peel, a major byproduct of essential oil extraction. Journal of Agricultural Food Chemistry. 2006:54:197-203.

[4] Silva VM, Viotto LA. Drying of sicilian lemon residue: influence of process variables on the evaluation of the dietary fiber produced. Ciênc. Tecnol. Aliment., Campinas. 2010: 30(2): 421-428.

[5] Russo M, Bonaccorsi I, Torre G, Sarò M, Dugo P, Mondello L. Underestimated sources of flavonoids, limonoids and dietary fiber: availability in lemon’s by-products. Journal of Functional Foods. 2014:9:18-26.

[6] Bingham SA. Dietary fiber in food and production against colorectal cancer in the European prospective investigation into cancer and nutrition (EPIC): An observational study. Lancet. 2003:361: 1496-1499.

[7] Mildner-Szkudlarz S, Siger A, Szwengiel A, Bajerska J. Natural compounds from grape by-products enhance nutritive value and reduce formation of CML in model muffins. Food Chemistry. 2015:172: 78-85.

[8] Danesi EDG, Granato D, Iwassa IJ, Pinzon C, Bolanho BC. Effects of industrial by-products from orange, peach palm and soybean on the quality traits and antioxidant activity of flours: a response surface approach. International Food Research Journal. 2018:25(3): 1219-1227.

[9] Kaysar MI, Khandoker S, Islam MS, Mia MS, Kausar AKMG. Productivity and profitability of mandarin cultivation in selected areas of Bangladesh. Journal of Bioscience and Agriculture Research. 2017:14(01): 1174-1182.

[10] Janati SSF, Beheshti HR, Feizy J, Fahim NK. Chemical composition of lemon (citrus limon) and peels its considerations as animal food. Gida. 2012:37 (5): 267-271.

[11] Garau MC, Simal S, Rosselló C, Femenia A. Effect of air-drying temperature on physico-chemical properties of dietary fibre and antioxidant capacity of orange (Citrus aurantium v. Canoneta) by-products. Food Chemistry. 2007:104: 1014-1024.

[12] Norafida A. Aminah A. Effect of blanching treatments on antioxidant activity of frozen green Capsicum (Capsicum annuum L. var bell pepper). International Food Research Journal. 2018:25(4): 1427-1434.

[13] Akter MS, Ahmed M, Jong-Bang E. Effect of blanching and drying temperatures on the physicochemical characteristics, dietary fiber composition and antioxidant-related parameters of dried persimmons peel powder. International Journal of Food Sciences and Nutrition. 2010:61(7): 702-712.

[14] Larrauri JA. New approaches in the preparation of high dietary fiber powders from fruit by-products. Trends in Food Science and Technology. 1999:10(1): 3-8.

[15] Marey S, Shoughy M. Effect of temperature on the drying behavior and quality of citrus peels. International Journal of Food Engineering. 2016:12(7): 661-671.

[16] AOAC. Official methods of analysis, $18^{\text {th }}$ ed. Association of Official Analytical Chemists, AOAC International, Gaithersburg, MD, USA. 2005.

[17] AOAC. Official methods of analysis. Association of Official Analytical Chemists. Washington, D.C. 1984.

[18] Ranganna S. Handbook of analysis of fruit and vegetable products. TataMc-Graw Hill Publishing Co. Ltd., New Delhi. 2009.

[19] Vega-Gálvez A, Lemus-Mondaca R, Bilbao- Saniz C, Fito P, Andrés A. Effect of air drying temperature on the quality of rehydrated dried red bell pepper (Capsicum annuum L.). Journal of Food Engineering. 2008:85 (1): 42-50.

[20] Saxena A, Maity T, Raju PS, Bawa AS. Degradation kinetics of colour and total carotenoids in Jackfruit (Artocarpusheterophyllus) bulb slices during hot air drying. Food Bioprocess Technology. 2012:5: 672-679.

[21] Ashoush IS, Gadallah MGE. Utilization of mango peels and seed kernels powders as sources of phytochemicals in biscuit. World Journal of Dairy and Food Sciences. 2011:6 (1): 35-42.

[22] Wiriyaumpaiwong S, Wiset L. Thin layer drying equation and the changes in color of celery under different drying temperatures. Journal of Agricultural Science. 2008:39:323-326.

[23] Galoburda R, Kuka M, Cakste I, Klava D. The effect of blanching temperature on the quality of microwavevacuum dried mushroom Cantharellus cibarius. Agronomy Research. 2015:13(4): 929-938.

[24] Thebaudin JY, Lefebvre AC, Harrington M, Bourgeois CM. Dietary fibers: nutritional and technological interest. Trends in Food Science and Technology. 1997:8(2):41-48.

[25] Férnandez-Lopez J, Fernández-Ginés JM, Aleson-Carbonell L, Sendra E. Application of functional citrus byproducts to meat products. Trends in Food Science and Technology. 2004:15 (3-4): 176-185.

[26] Aleson-Carbonell L, Fernández-López J, Pérez-Álvarez JA, Kuri V. Characteristics of beef burger as influenced by various types of lemon albedo. Innovative Food Science and Emerging Technologies. 2005:6 (2): 247-255. 
[27] Sendra E, Fayos P, Lario Y, Fernández-López J, Sayas-Barberá E, Pérez-Alvarez JA. Incorporation of citrus fibers in fermented milk containing probiotic bacteria. Food Microbiology. 2008:25(1): 13-21.

[28] Ajila CM, Leelavathi K, Prasada Rao UJS. Improvement of dietary fiber content and antioxidant properties in soft dough biscuits with the incorporation of mango peel powder. Journal of Cereal Science. 2008:48: 319326.

[29] Jorge A, Almeida DM, Canteri MHG, Sequinel T, Kubaski ET, Tebcherani SM. Evaluation of the chemical composition and colour in long life tomatoes (Lycopersicon esculentum Mill) dehydrated by combined drying methods. International Journal of Food Science and Technology. 2014:49:2001-2007.

(C) 2021 by the author(s). This work is licensed under a Creative Commons Attribution 4.0 International License (http://creativecommons.org/licenses/by/4.0/). Authors retain copyright of their work, with first publication rights granted to Tech Reviews Ltd. 